\title{
OPTIMASI QUERY PADA LAPORAN TRANSAKSI PENJUALAN MENGGUNAKAN MATERIALIZED VIEW (Studi Kasus : Moonly café)
}

\author{
Febrianta Surya Nugraha ${ }^{1}$ \\ Febryan Hari Purwanto ${ }^{2}$ \\ Fachruddin Edi Nugroho Saputro ${ }^{3}$ \\ ${ }^{1,3}$ Mahasiswa Magister Teknik Informatika Universitas AMIKOM Yogyakarta \\ ${ }^{2}$ Akademi Farmasi Al-Fatah Bengkulu \\ E-mail: ${ }^{1}$ ubingg@gmail.com, \\ 2fharipurwanto@gmail.com, \\ fensdin@gmail.com.
}

Diterima: 2 Januari 2018/ Disetujui : 19 Januari 2018

\begin{abstract}
The development of café business in Yogyakarta in 2017 is growing very rapidly. Moonly café currently uses sales information system using android platform and use data storage through cloud computing. The growing business café, transactions are done every day more and more. Sales information system runs slower when accessing larger data. These problems illustrate the lack of efficient time in data processing and the necessity of using query optimization in accessing data to speed up the process. The purpose of this study is to determine the speed performance in displaying monthly sales report by using query where clause, view table and materialized view table. The database is using MySql Server accessed via the internet, then recorded for the monthly sales report. In addition to comparing the performance of speed in displaying monthly sales reports, the authors also compare the speed of queries in displaying the report the amount of sales of each item each month on the table results of sales reports generated either from the query, view tables or materialized view tables. Use of materialized view to display monthly sales transaction reports faster than using query where clause or view. The use of materialized view to display reports the number of sales of each item each month faster than using the query where clause and view.
\end{abstract}

Keyword : Database, Query optimization, Materialized view

\begin{abstract}
ABSTRAK
Perkembangan bisnis café di Yogyakarta tahun 2017 berkembang sangat pesat. Moonly café saat ini menggunakan sistem informasi penjualan menggunakan platform android serta menggunakan data penyimpanan melalui cloud computing. Semakin berkembangnya bisnis café, transaksi yang dilakukan setiap harinya semakin besar. Sistem informasi penjualan berjalan lebih lambat ketika mengakses data yang semakin besar. Dari permasalahan tersebut menggambarkan kurangnya efisien waktu dalam pemrosesan data dan perlunya penggunaan optimasi query dalam pengaksesan data untuk mempercepat proses tersebut. Tujuan dari penelitian ini adalah untuk mengetahui performa kecepatan dalam menampilkan laporan penjualan bulanan dengan menggunakan query where clause, tabel view dan tabel materialized view. Database menggunakan MySql server yang diakses melalui internet, kemudian dicatat waktunya untuk proses menampilkan laporan penjualan bulanan. Selain membandingkan performa kecepatan dalam menampilkan laporan penjualan bulanan, penulis juga membandingkan kecepatan query dalam menampilkan laporan jumlah penjualan masing-masing item tiap bulan pada tabel hasil laporan penjualan yang dihasilkan baik dari query, tabel view maupun tabel materialized view. Penggunaan materialized view untuk menampilkan laporan transaksi penjualan bulanan lebih cepat dari pada menggunakan query where clause maupun view.
\end{abstract}


Penggunaan materialized view untuk menampilkan laporan jumlah penjualan masing-masing item tiap bulan lebih cepat dari pada menggunakan query where clause maupun view.

Kata kunci: Database, Optimasi query, Materialized view

\section{PENDAHULUAN}

Perkembangan bisnis café di Yogyakarta tahun 2017 berkembang sangat pesat. Penduduk yang heterogen dan kebiasaan masyarakat Yogyakarta yang sebagian besar dari kalangan mahasiswa mempunyai kebiasaan nongkrong serta diskusi di café. Semakin maraknya café-café di Yogyakarta membuat pengelola café harus berinovasi dengan menu-menu yang disajikan. Semakin banyaknya menu yang disajikan dengan kombinasi berbagai bahan baku yang semakin banyak, membuat prosesproses yang dilakukan di cafe secara manual berjalan dengan lambat. Oleh sebab itu, pengelola café mulai berfikir untuk menggunakan sistem informasi penjualan.

Dengan meningkatnya mobilitas masyarakat, pemilik café ingin dapat melihat dan memantau transaksi secara on-line atau dengan tidak perlu berada di café dengan memanfaatkan teknologi komputasi awan (cloud computing). Komputasi awan atau cloud computing dapat diartikan sebagai suatu teknologi yang memanfaatkan internet sebagai resource untuk komputasi yang dapat di-request oleh pengguna dan merupakan sebuah layanan dengan pusat server bersifat virtual atau berada dalam cloud (internet) itu sendiri [1].

Sistem informasi penjualan saat ini sudah berkembang dengan menggunakan data penyimpanan pada cloud computing. Semakin berkembangnya bisnis café, transaksi yang dilakukan setiap harinya semakin besar. Sistem informasi penjualan berjalan lebih lambat ketika mengakses data yang semakin besar. Dari permasalahan tersebut menggambarkan kurangnya efisien waktu dalam pemrosesan data dan perlunya penggunaan optimasi query dalam pengaksesan data untuk mempercepat proses tersebut.

View merupakan cara efisien untuk merepresentasikan data tanpa harus memeliharanya. View bukan merupakan tabel, dan bersifat virtual yang tidak membutuhkan storage tetap. View memiliki baris dan kolom seperti tabel, namun untuk dapat melakukan insert, update atau delete tergantung pada definisi view itu sendiri. Penggunaan view biasanya ditujukan untuk alasan keamanan data yang sensitif. Selain itu view juga dapat digunakan untuk mengubah tabel tanpa mempengaruhi aplikasi, memungkinkan untuk mengakses informasi lebih dari satu sumber, dan melakukan summary terhadap tabel seperti sum, min, max atau rata-rata [2]. Materialized view adalah tabel dinamis yang tidak hanya berisi perintah query SQL untuk menghasilkan baris, tetapi menyimpan baris yang sebenarnya. Materialized view dibuat saat pertama kali query dijalankan, dan baris ringkasan disimpan dalam tabel. Baris materialized view secara otomatis diperbarui saat tabel dasar diperbarui [3].

Moonly Café merupakan salah satu usaha kuliner di Yogyakarta yang beralamat di Jl. Menteri Supeno No 101, Umbulharjo Yogyakarta. Moonly Café berdiri sejak 1 April 2016 dan mempunyai 8 karyawan. Target pasar dari Moonly Café yaitu mahasiswa, siswa dan karyawan yang berada di Yogyakarta. Moonly cafe saat ini menggunakan sistem informasi penjualan menggunakan platform android serta menggunakan data penyimpanan melalui cloud computing. Laporan penjualan digunakan untuk pengontrolan penjualan setiap harinya oleh manajer operasional. Pengontrolan penjualan berkaitan langsung dengan stok dan bahan baku yang harus dibelanjakan setiap harinya. Selain itu laporan juga berfungsi untuk mengetahui marketshare penjualan, mengetahui grafik penjualan berdasarkan target pasar yg telah ditentukan, dan dapat berfungsi sebagai bahan evaluasi kinerja karyawan serta mengetahui selera pasar untuk inovasi kedepan yang disesuaikan dengan keinginan pelanggan. Selain manajer operasional, laporan penjualan digunakan pemilik cafe untuk evaluasi secara keseluruhan.

Penelitian terdahulu tentang materializedviewantara lain adalahan approach for query optimization by using schema object base view [4], kompleksitas query sangat meningkatkan biaya eksekusi dari query yang memiliki efek kritis terhadap kinerja dan produktivitas sistem pendukung keputusan. Hal ini diperlukan untuk melakukan operasi penggabungan dan penggabungan berat yang sering dilakukan di database. Jika tidak dihitung sebelumnya, maka akan mengurangi kinerja query. Objek skema tidak hanya mendefinisikan hubungan, tapi juga memungkinkan untuk menghitung ulang join dan agregat yang besar yang menghasilkan kinerja query yang optimal. Objek skema 
menyebabkan penurunan biaya pemrosesan query dan biaya pemeliharaan query dalam hal faktor waktu. Objek skema meningkatkan kinerja query dengan menghitung operasi penggabungan dan penggabungan yang berat pada database sebelum eksekusi dan menyimpan hasilnya di database. Keuntungan besar dari pandangan berbasis objek skema adalah pengambilan data agregat yang sangat cepat, karena dihitung dan disimpan, dengan mengorbankan insert / update / delete sehingga meningkatkan kinerja query daripada view dan tabel biasa. Hasil dari penelitian ini adalah kegunaan MV dalam menulis ulang query dan mengusulkan algoritma penulisan ulang yang terdiri dari tiga langkah utama. Pada langkah pertama, ia memilih MV yang akan digunakan untuk menulis ulang dan menentukan daerah query tersebut. Pendekatan sebelumnya berfokus pada optimalisasi query menggunakan agregasi dan bekerja pada satu blok query sementara di sini penulis menyajikan kegunaan skema objek sebagai tambahan dengan pekerjaan yang ada dan bekerja pada query multi blok. Pada langkah kedua, ia menghasilkan blok query untuk MV yang dipilih menggunakan wilayah query tersebut. Langkah terakhir mengintegrasikan blok query ke dalam query terakhir yang dapat ditulis Ini menggunakan kelas MV yang jauh lebih luas dan menghasilkan jenis penulisan ulang yang lebih umum daripada pendekatan sebelumnya.

Optimasi query database menggunakan teknik heuristik[5],heuristic optimizationatau yang biasanya disebut dengan rulebasedoptimization adalah optimisasi query dengan menggunakan aturanaturan heuristik dan dijalankan pada logical query plan (rencana query secara logika) yang terdiri dari urutan operasi-operasi relasional yang biasanya digambarkan sebagai query tree. Query optimizer mendapatkan sebuah inisial plan dari parser dan menggunakan aturan-aturan heuristik untuk mentransformasikan sebuah query ke dalam sebuah bentuk yang sama sehingga dapat diproses dengan lebih efisien. Hasil dari penelitian ini adalah optimisasi query berhubungan dengan teknikteknik yang digunakan oleh DBMS (Database Manajemen Sistem) untuk memproses query agar diperoleh hasil query dengan waktu akses yang minimum. Terdapat 4 tahap yang harus dilakukan dalam optimisasi sebuah query, yaitu memasukkan query ke dalam representasi internal berdasarkan ekspresi aljabar yang sesuai; Mengkonversikannya ke dalam bentuk canonical dengan cara mula-mula dengan menggunakan cartesianproduct dari klausa FROM kemudian menggabungkan dan memilih kondisi-kondisi dari klausa WHERE dan melakukan proyeksi-proyeksi dari klausa SELECT; Memilih calon-calon prosedur lowlevel, yaitu mempertimbangkan index atau jalan akses lainnya, membagi nilai-nilai penyimpanan data dari record untuk memilih satu atau lebih calon-calon prosedur untuk mengimplementasikan tiap-tiap operasi lowlevel dalam query; Menghasilkan rencana-rencana query dan memilih yang termurah, yaitu membuat sekumpulan calon rencana-rencana query dan kemudian memilih yang termurah.

Design and implementation of algorithms for materialized view selection and maintenance in data warehousing environment [6], data warehouse, data mining dan pemrosesan analisis online merupakan beberapa tren terbaru dalam lingkungan komputasi dan aplikasi teknologi informasi untuk pemrosesan dan analisis data berskala besar. Teknologi data warehouse menjadi penting untuk perumusan strategi dan perumusan strategi bisnis yang efektif. Untuk keberhasilan setiap data warehouse, informasi konsolidasi yang akurat dan tepat waktu bersamaan dengan waktu respons query yang cepat dan efektif merupakan persyaratan dasar yang mendasar. Materializationviews secara praktis tidak mungkin karena adanya ruang penyimpanan dan batasan biaya pemeliharaan yang terwujud sehingga pemilihan materialized view dengan baik merupakan salah satu keputusan cerdas dalam merancang gudang data untuk mendapatkan efisiensi yang optimal. Dalam makalah ini, penulis menyajikan kerangka kerja untuk memilih materializedview terbaik sehingga dapat mencapai kombinasi yang efektif dari waktu respons query yang baik, biaya pemrosesan query yang rendah dan biaya perawatan tampilan rendah dalam batasan ruang penyimpanan tertentu. Parameter implementasi kerangka kerja mencakup biaya frekuensi query, biaya penyimpanan query dan biaya pemrosesan query. Kerangka kerja penelitian ini memilih biaya terbaik yang efektif padamaterlized view untuk mengoptimalkan waktu pemrosesan query sehingga menghasilkan sistem data warehouse yang efisien.

Tujuan dari penelitian ini adalah untuk mengetahui performa kecepatan dalam menampilkan laporan penjualan bulanan dengan menggunakan query where clause, tabel view dan tabel materialized view. Database diletakan pada server yang diakses melalui internet, kemudian dicatat waktunya untuk proses menampilkan laporan penjualan bulanan. Selain membandingkan performa kecepatan dalam menampilkan laporan penjualan bulanan, penulis juga membandingkan kecepatan 
query dalam menampilkan laporan jumlah penjualan masing-masing item tiap bulan pada tabel hasil laporan penjualan yang dihasilkan baik dari querywhereclause, tabel view maupun tabel materializedview.

\section{METODE PENELITIAN}

Penelitian ini terdiri dari 3 tahapan, yaitu tahap persiapan, eksperimen dan analisis hasil. Pada tahap persiapan, dimulai dengan mengumpulkan beberapa data transaksi penjualan pada Moonly Café kemudian dilakukan normalisasi untuk membuat relasi tabel. Setelah itu dilakukan pembuatan database di server dari data transaksi penjualan dan relasi tabel.

Pada tahap eksperimen, dilakukan eksperimen pembuatan dan menampilkan transaksi penjualan bulanan dengan menggunakan operasi whereclause,view dan materializedviewkemudian dicatat lamanya waktu proses. Pada tahap eksperimen juga dilakukan eksperimen query untuk menampilkanlaporan jumlah penjualan masing-masing item tiap bulan dari hasil menanpilkan penjualan bulanan dengan menggunakan operasi where clause, view dan materializedview.

Pada tahap analisis hasil, dilakukan pembuatan rekapitulasi hasil dari eksperimen yang dilakukan, kemudian dibandingkan hasil dari eksperimen tersebut. Alur penelitian dapat dilihat pada gambar 1.

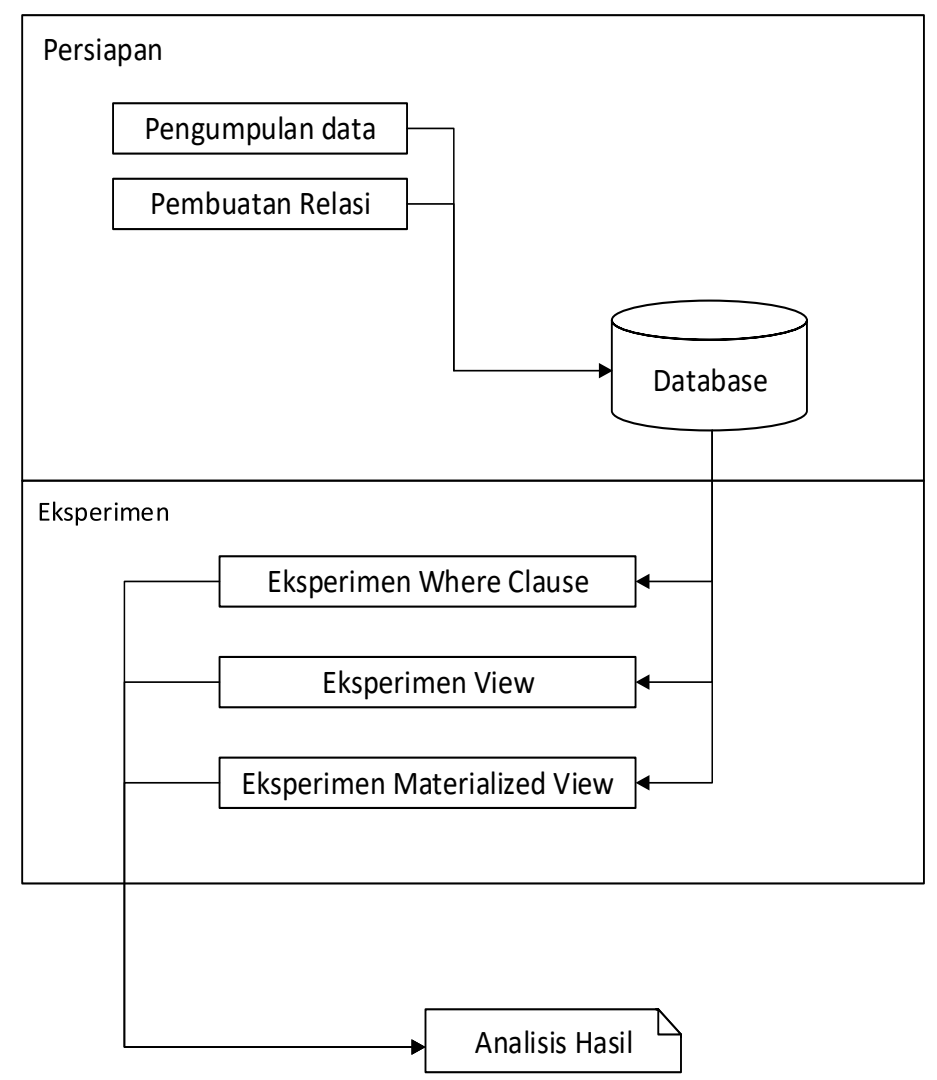

Gambar 1. Alur Penelitian 


\section{HASIL DAN PEMBAHASAN}

\subsection{Tahap Persiapan}

Pada tahap persiapan, dimulai dengan mengumpulkan beberapa data transaksi penjualan pada Moonly Café kemudian dilakukan normalisasi untuk membuat struktur tabel. Dari struktur tabel dibuat relasi tabel yang akan digunakan untuk pembuatan database. Setelah database dibuat, data yang semula berbentuk excel perlu diubah menjadi csv supaya dapat dimasukan kedalam database. Tahap terakhir sebelum melakukan eksperimen adalah pengecekan konektifitas komputer dan server yang digunakan untuk eksperimen.

\begin{tabular}{|c|c|c|c|c|c|c|}
\hline Nomor & Tanggal & Pelanggan & Item & Qty Harga Satuan & Jumlah & Total \\
\hline$S / 170409 / 1$ & 2017-04-09, 17:13 & - & Teh Panas & 1 Rp. 4.000 & Rp. 4.000 & Rp. 4.000 \\
\hline \multirow[b]{5}{*}{$S / 170409 / 2$} & \multirow[b]{5}{*}{ 2017-04-09, 19:05 } & \multirow[b]{5}{*}{ - } & French Fries & 1 Rp. 8.000 & Rp. 8.000 & \multirow[b]{5}{*}{ Rp. 46.000} \\
\hline & & & Jamur Pedas Cryspi & 1 Rp. 7.000 & Rp. 7.000 & \\
\hline & & & Mie Telur Goreng & 1 Rp. 9.000 & Rp. 9.000 & \\
\hline & & & Milkshake Coklat & 1 Rp. 11.000 & Rp. 11.000 & \\
\hline & & & Milkshake Vanilla & 1 Rp. 11.000 & Rp. 11.000 & \\
\hline \multirow[b]{7}{*}{$S / 170409 / 3$} & \multirow[b]{7}{*}{ 2017-04-09, 19:22 } & \multirow[b]{7}{*}{ - } & Air Mineral & 2 Rp. 4.000 & Rp. 8.000 & \multirow[b]{7}{*}{ Rp. 70.000} \\
\hline & & & Ice Cream Vanilla & 1 Rp. 8.000 & Rp. 8.000 & \\
\hline & & & Jus Alpukat & 1 Rp. 10.000 & Rp. 10.000 & \\
\hline & & & Jus Mangga & 2 Rp. 10.000 & Rp. 20.000 & \\
\hline & & & Lemon Squash & 2 Rp. 8.000 & Rp. 16.000 & \\
\hline & & & Lemon Tea & 1 Rp. 6.000 & Rp. 6.000 & \\
\hline & & & Air Putih & 2 Rp. 1.000 & Rp. 2.000 & \\
\hline \multirow[b]{4}{*}{$S / 170409 / 4$} & \multirow[b]{4}{*}{$2017-04-09,19: 29$} & & Cappucino & 1 Rp. 7.000 & Rp. 7.000 & \multirow[b]{4}{*}{ Rp. 26.000} \\
\hline & & & Susu Jahe & 1 Rp. 7.000 & Rp. 7.000 & \\
\hline & & & Vanila Late & 1 Rp. 6.000 & Rp. 6.000 & \\
\hline & & - & Vanila Late & 1 Rp. 6.000 & Rp. 6.000 & \\
\hline \multirow[b]{2}{*}{$S / 170409 / 5$} & \multirow[b]{2}{*}{ 2017-04-09, 19:31 } & \multirow[b]{2}{*}{-} & Milkshake Vanilla & 1 Rp. 11.000 & Rp. 11.000 & \multirow[b]{2}{*}{ Rp. 17.000} \\
\hline & & & Pisang Goreng Krispy & 1 Rp. 6.000 & Rp. 6.000 & \\
\hline \multirow{8}{*}{$S / 170409 / 6$} & \multirow{8}{*}{ 2017-04-09, 19:44 } & & Air Mineral & 1 Rp. 4.000 & Rp. 4.000 & \multirow{8}{*}{ Rp. 67.000} \\
\hline & & & French Fries & 1 Rp. 8.000 & Rp. 8.000 & \\
\hline & & & Jeruk Panas & 1 Rp. 6.000 & Rp. 6.000 & \\
\hline & & & Jus Alpukat & 1 Rp. 10.000 & Rp. 10.000 & \\
\hline & & & Jus Mangga & 1 Rp. 10.000 & Rp. 10.000 & \\
\hline & & & Lemon Squash & 2 Rp. 8.000 & Rp. 16.000 & \\
\hline & & - & Strawberry Float & 1 Rp. 13.000 & Rp. 13.000 & \\
\hline & & & Air Putih & 1 Rp. 1.000 & Rp. 1.000 & \\
\hline
\end{tabular}

Gambar 2. Contoh Data Laporan Penjualan Moonly Cafe

Data transaksi penjualan pada Moonly cafe yang berbentuk excel dapat dilihat pada gambar 2 . Dari data transaksi laporan penjualan, dilakukan normalisasi sehingga didapatkan struktur tabel database yang dapat dilihat pada tabel 1 . 
Tabel 1. Struktur Tabel database

Tabel bahanpenyusun

\begin{tabular}{|c|c|c|}
\hline Nama & Jenis & Deskripsi \\
\hline IdItem (FK) & $\operatorname{varchar}(5)$ & Kode barang \\
\hline IdBahan & $\operatorname{varchar}(5)$ & Kode bahan penyusun \\
\hline QtyBahan & $\operatorname{int}(10)$ & Jumlah bahan Penyusun \\
\hline \multicolumn{3}{|l|}{ Tabel detailtransaksi } \\
\hline Nama & Jenis & Deskripsi \\
\hline NoTransaksi (FK) & varchar(20) & Nomor Nota \\
\hline IdItem (FK) & $\operatorname{varchar}(5)$ & Kode barang \\
\hline Qty & $\operatorname{int}(10)$ & Jumlah pembelian \\
\hline HargaSatuan & $\operatorname{int}(20)$ & Harga satuan \\
\hline \multicolumn{3}{|l|}{ Tabel item } \\
\hline Nama & Jenis & Deskripsi \\
\hline IdItem (PK) & varchar(5) & Kode barang \\
\hline NamaItem & varchar(50) & Nama barang \\
\hline IdKategori (FK) & $\operatorname{varchar}(5)$ & Kode kategori barang \\
\hline Satuan & $\operatorname{varchar}(5)$ & Satuan \\
\hline HargaJual & $\operatorname{int}(20)$ & Harga jual \\
\hline HargaBeli & $\operatorname{int}(20)$ & Harga beli \\
\hline JenisProdukBahan & varchar(10) & Jenis produk atau bahan \\
\hline Foto & $\operatorname{varchar}(255)$ & Gambar produk \\
\hline \multicolumn{3}{|l|}{ Tabel kategori } \\
\hline Nama & Jenis & Deskripsi \\
\hline IdKategori (PK) & $\operatorname{varchar}(5)$ & Kode kategori barang \\
\hline Kategori & varchar(30) & Nama kategori \\
\hline \multicolumn{3}{|l|}{ Tabel outlet } \\
\hline Nama & Jenis & Deskripsi \\
\hline IdOutlet(PK) & $\operatorname{varchar}(5)$ & Kode outlet \\
\hline NamaOutlet & $\operatorname{varchar}(40)$ & Nama outlet \\
\hline AlamatOutlet & varchar(100) & Alamat outlet \\
\hline Telp & varchar(15) & Nomor Telepon \\
\hline \multicolumn{3}{|l|}{ Tabel pelanggan } \\
\hline Nama & Jenis & Deskripsi \\
\hline IdPelanggan $(\mathrm{PK})$ & $\operatorname{varchar}(5)$ & Kode pelanggan \\
\hline NamaPelanggan & varchar(30) & Nama pelanggan \\
\hline Email & $\operatorname{varchar}(50)$ & Email pelanggan \\
\hline $\mathrm{NoHp}$ & varchar(15) & Nomor handphone pelanggan \\
\hline TglLahir & date & Tanggal lahir pelanggan \\
\hline Alamat & $\operatorname{varchar}(100)$ & Alamat pelanggan \\
\hline \multicolumn{3}{|l|}{ Tabeltransaksi } \\
\hline Nama & Jenis & Deskripsi \\
\hline NoTransaksi (PK) & varchar(20) & Nomor transaksi \\
\hline TglTransaksi & date & Tanggal transaksi \\
\hline IdOutlet (FK) & $\operatorname{varchar}(5)$ & Kode outlet \\
\hline IdPelanggan $(\mathrm{FK})$ & $\operatorname{varchar}(5)$ & Kode pelanggan \\
\hline
\end{tabular}


Dari beberapa tabel yang dihasilkan, untuk melihat hubungan antar tabel dibuatlah relasi tabel. Tanda PK merupakan kunci utama, sedangkan tanda FK adalah kunci tamu yang ditentukan oleh arah panah. Relasi tabel dapat dilihat pada gambar 3.

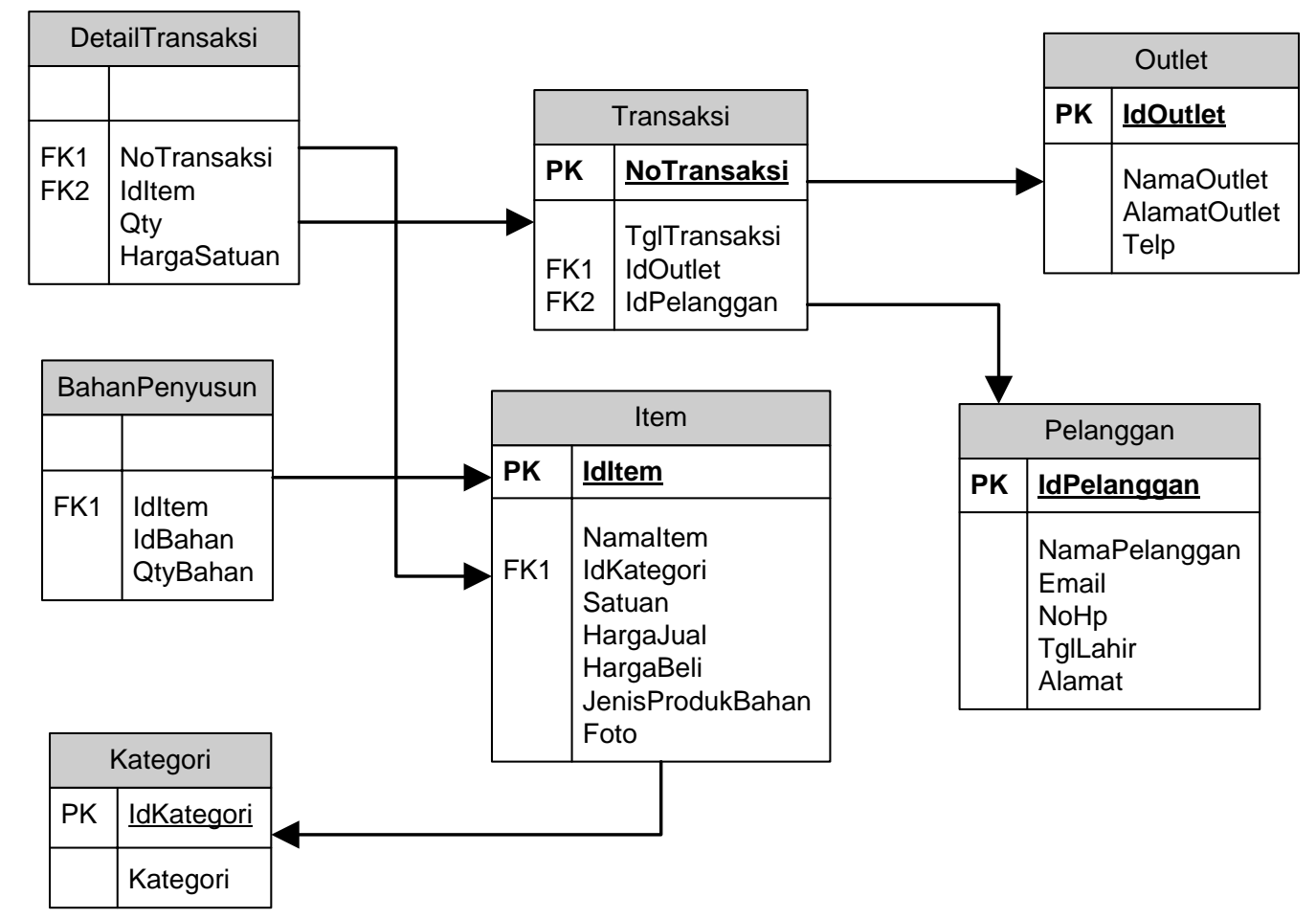

\section{Gambar 3. Relasi Tabel}

Berdasarkan relasi tabel dan data-data yang sudah diubah kedalam format csv, dibuatlah database yang terletak pada server cloud yang diakses melalui internet. DBMS (database management system) yang digunakan adalah MySQL yang diakses menggunakan web browser melalui phpmyadmin.Gambaran umum topologi dapat dilihat pada gambar 4.

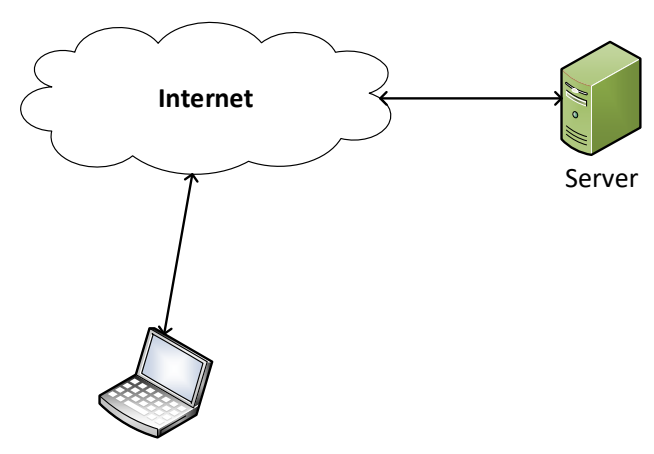

Gambar 4. Gambaran Umum Topologi

Database yang dibuat dari hasil normalisasi sebelumnya diletakan pada server yang di akses melalui internet yang beralamat pada https://nazira.kingofserver.net dengan konfigurasi sebagai berikut.

\section{Database server}

Server: Localhost via UNIX socket

Server type: MySQL

Server version: 5.6.35-cll-lve - MySQL Community Server (GPL) 
Protocol version: 10

User: akfaralf_moonly@localhost

Database Name :akfaralf_dbmoonlycafe

Server charset: UTF-8 Unicode (utf8)

Web server

cpsrvd 11.64.0.22

Database client version: libmysql - 5.1.73

PHP extension: mysqliDocumentation curlDocumentation mbstringDocumentation

PHP version: 5.6.30

phpMyAdmin Version information: 4.6.6

Untuk membandingkan performa kecepatan penggunaan query where clause, tabel view dan tabel materialized view, penulis menggunakan tool phpmyadmin versi 4.6.6 yang terinstall pada server. Untuk mengakses phpmyadmin dan menjalankan perintah query digunakan browser Google Chrome Versi 58.0.3029.110 yang terinstal pada notebook dengan spesifikasi Intel DualCore T3400 2.16GHz, 2048MB DDR2, dan sistem operasi Windows 7 Ultimate 32 Bit. Koneksi yang digunakan menggunakan koneksi internet dengan jaringan HSDPA+ dan nilai ping ke server saat penelitian adalah nilai minimum $261 \mathrm{~ms}$, maximum $630 \mathrm{~ms}$, dan rata-rata $386 \mathrm{~ms}$ yang dapat dilihat pada gambar 5 dan tampilan phpmyadmin pada gambar 6.

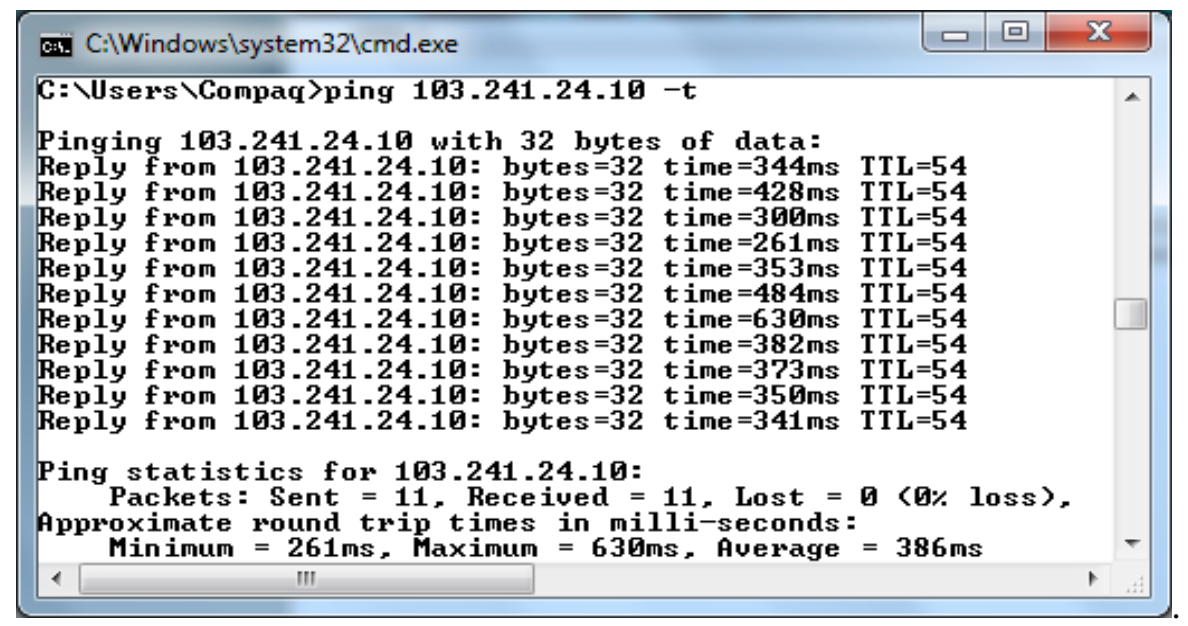

Gambar 5. Hasil Ping ke Server

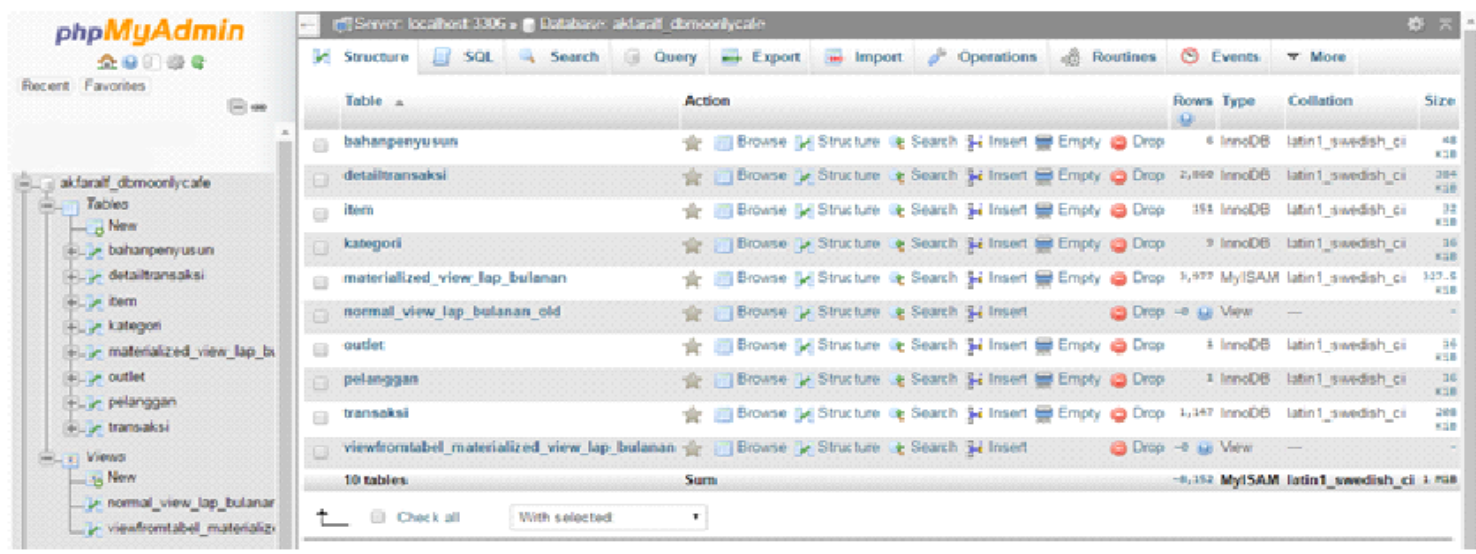

Gambar 6. Tampilan PhpMyAdmin Server

\subsection{Eksperimen}

Setelah dilakukan import struktur dan data ke database, dilakukan pengujian untuk mengetahui performa kecepatan dalam menampilkan data laporan penjualan bulanan dan 
menampilkan laporan jumlah penjualan masing-masing item pada bulan tertentudengan menggunakan querywhere clause, view, dan materialized view. Masing-masing pengujian dilakukan sebanyak 5 kali pengujian yang terdiri dari pengujian dengan 100, 500, 750, 1000, dan 1500 baris data.

\subsubsection{Eksperimen Menggunakan Where Clause}

Query yang digunakan dalam eksperimen menampilkan laporan transaksi penjualan bulanan menggunakan query where clause dapat dilihat pada query 1 dan menampilkan laporan jumlah penjualan masing-masing item pada bulan tertentu pada query 2 .

Query 1. Menampilkan Laporan Bulanan Dengan Query Where Clasue

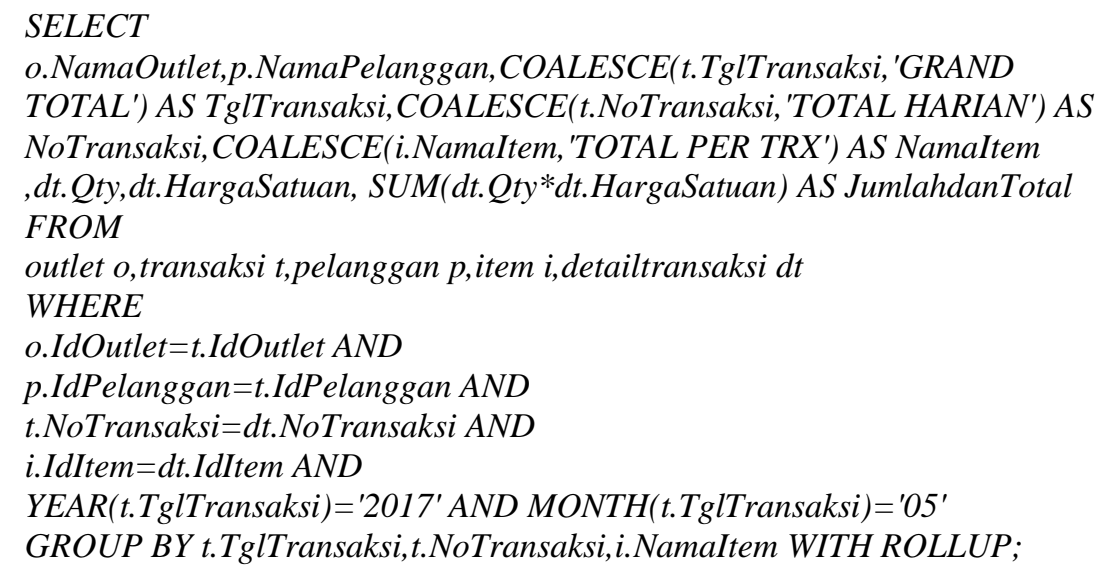

Query 2. Menampilkan Laporan Jumlah Penjualan Masing-Masing Item Pada Bulan Tertentu Dengan Query WhereClause

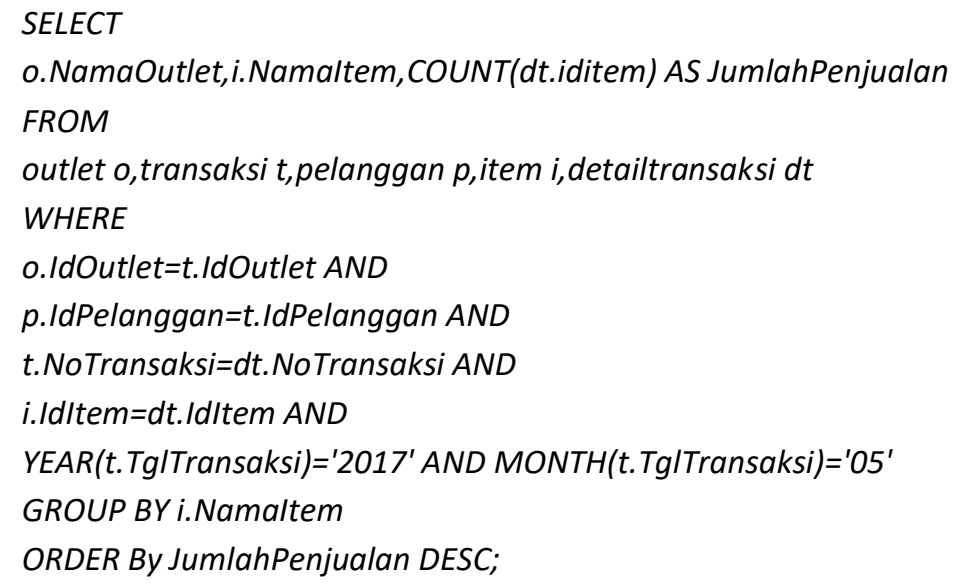

Hasil pengujian query 1 menampilkan laporan bulanan dan query 2 untuk menampilkan laporan jumlah penjualan masing-masing item pada bulan tertentu dengan query whereclause dapat dilihat pada tabel 2 . 
Tabel 2. Hasil Pengujian Menggunakan Where Clause

\begin{tabular}{|c|c|c|c|c|c|}
\hline Parameter & $\begin{array}{c}\text { Pengujian } \\
\text { 100 Baris }\end{array}$ & $\begin{array}{c}\text { Pengujian } \\
\text { 500 Baris }\end{array}$ & $\begin{array}{c}\text { Pengujian } \\
750 \text { Baris }\end{array}$ & $\begin{array}{c}\text { Pengujian } \\
1000 \\
\text { Baris }\end{array}$ & $\begin{array}{c}\text { Pengujian } \\
1500 \\
\text { Baris }\end{array}$ \\
\hline Query 1 & 0.007 & 0.0072 & 0.0072 & 0.008 & 0.0076 \\
\hline Query 2 & 0.0039 & 0.0045 & 0.0037 & 0.0045 & 0.004 \\
\hline
\end{tabular}

\subsubsection{Eksperimen Menggunakan View}

Sebelum dilakukan pengujian menampilkan laporan transaksi penjualan bulanan menggunakan view, dibuat tabelview terlebih dahulu dengan query sebagai berikut.

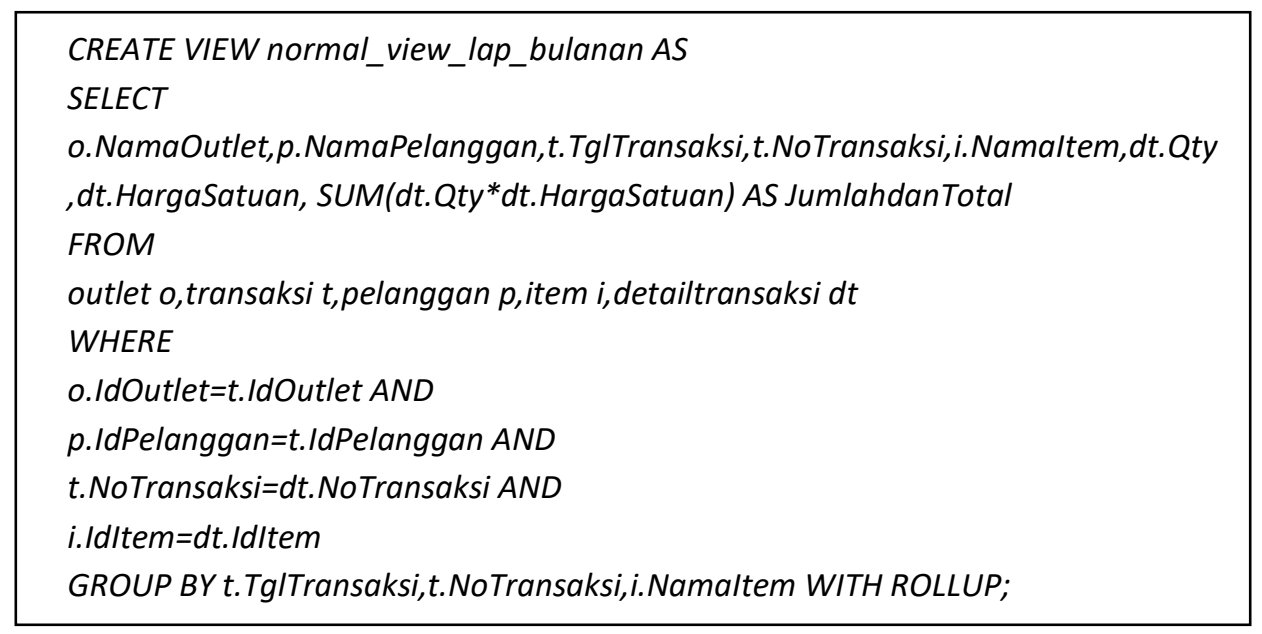

Query yang digunakan dalam eksperimen menampilkan laporan transaksi penjualan bulanan menggunakan view dapat dilihat pada query 3 dan menampilkan laporan jumlah penjualan masingmasing item pada bulan tertentu pada query 4 .

Query 3. Menampilkan Laporan Bulanan MenggunakanView

SELECT * FROM normal_view_lap_bulanan

WHERE YEAR(Tg/Transaksi)='2017' AND MONTH(Tg/Transaksi)='05';

Query 4. Menampilkan Laporan Jumlah Penjualan Masing-Masing Item Pada Bulan Tertentu Menggunakan View

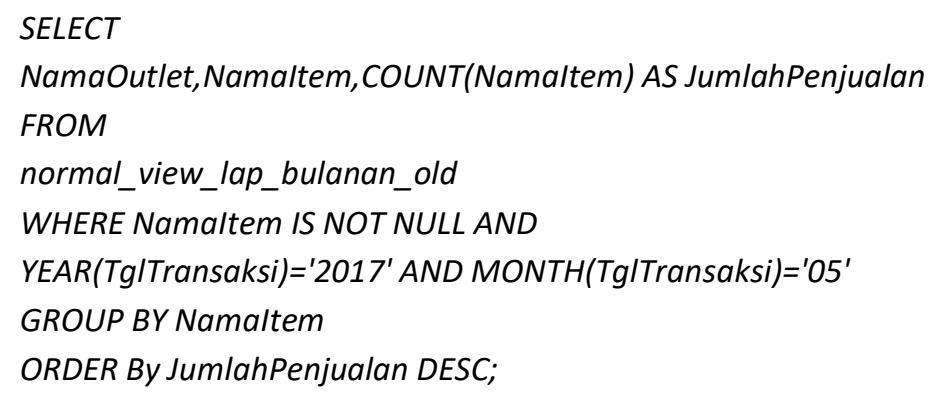

Hasil pengujian query 3 menampilkan laporan bulanan dan query 4 untuk menampilkan laporan jumlah penjualan masing-masing item pada bulan tertentu dengan menggunakan view dapat dilihat pada tabel 3 . 
Tabel 3. Hasil Pengujian Menggunakan View

\begin{tabular}{|l|c|c|c|c|c|}
\hline Parameter & $\begin{array}{c}\text { Pengujian } \\
\text { 100 Baris }\end{array}$ & $\begin{array}{c}\text { Pengujian } \\
\text { 500 Baris }\end{array}$ & $\begin{array}{c}\text { Pengujian } \\
750 \text { Baris }\end{array}$ & $\begin{array}{c}\text { Pengujian } \\
1000 \\
\text { Baris }\end{array}$ & $\begin{array}{c}\text { Pengujian } \\
1500 \\
\text { Baris }\end{array}$ \\
\hline Query 3 & 0.0105 & 0.0104 & 0.0111 & 0.0118 & 0.0124 \\
\hline Query 4 & 0.0209 & 0.0174 & 0.017 & 0.0129 & 0.0113 \\
\hline
\end{tabular}

\subsubsection{Eksperimen Menggunakan Materialized View}

Sebelum dilakukan pengujian menampilkan laporan transaksi penjualan bulanan menggunakan materializedview, dibuat tabel materialized view terlebih dahulu dengan query sebagai berikut.

CREATE TABLE materialized_view_lap_bulanan AS SELECT * FROM

normal_view_lap_bulanan;

RENAME TABLE normal_view_lap_bulanan TO normal_view_lap_bulanan_old;

CREATE VIEW viewfromtabel_materialized_view_lap_bulanan AS SELECT * FROM

materialized_view_lap_bulanan;

Query yang digunakan dalam eksperimen menampilkan laporan transaksi penjualan bulanan menggunakan materializedview dapat dilihat pada query 5 dan menampilkan laporan jumlah penjualan masing-masing item pada bulan tertentu pada query 6 .

Query 5. Menampilkan Laporan Bulanan MenggunakanMaterializedView

SELECT * FROM viewfromtabel_materialized_view_lap_bulanan

WHERE YEAR(TglTransaksi)='2017' AND MONTH(TglTransaksi)='05';

Query 6. Menampilkan Laporan Jumlah Penjualan Masing-Masing Item Pada Bulan Tertentu

Menggunakan MaterializedView

SELECT

NamaOutlet,Namaltem,COUNT(Namaltem) AS JumlahPenjualan

FROM

viewfromtabel_materialized_view_lap_bulanan

WHERE Namaltem IS NOT NULL AND

YEAR(TgITransaksi)='2017' AND MONTH(Tg/Transaksi)='05'

GROUP BY Namaltem

ORDER By JumlahPenjualan DESC;

Hasil pengujian query 5 menampilkan laporan bulanan dan query 6 untuk menampilkan laporan jumlah penjualan masing-masing item pada bulan tertentu dengan menggunakan materializedview dapat dilihat pada tabel 4. 
Tabel 4. Hasil Pengujian Menggunakan MaterializedView

\begin{tabular}{|l|c|c|c|c|c|}
\hline Parameter & $\begin{array}{c}\text { Pengujian } \\
\text { 100 Baris }\end{array}$ & $\begin{array}{c}\text { Pengujian } \\
\text { 500 Baris }\end{array}$ & $\begin{array}{c}\text { Pengujian } \\
750 \text { Baris }\end{array}$ & $\begin{array}{c}\text { Pengujian } \\
1000 \\
\text { Baris }\end{array}$ & $\begin{array}{c}\text { Pengujian } \\
1500 \\
\text { Baris }\end{array}$ \\
\hline Query 5 & 0.0012 & 0.0017 & 0.0017 & 0.002 & 0.0027 \\
\hline Query 6 & 0.0011 & 0.0022 & 0.0024 & 0.0024 & 0.0029 \\
\hline
\end{tabular}

\subsection{Analisis Hasil}

Berdasarkan eksperimen yang talah dilakukan, untuk mengetahui performa kecepatan pemrosesan query, perlu dilakukan perbandingan hasil eksperimen baik menggunakan query where clause, view, dan materializedview. Perbandingan performa kecepatan pemrosesan query untuk menampilkan laporan transaksi penjualan bulanan dapat dilhat pada tabel 5 dan gambar 7 .

Tabel 5. Hasil Perbandingan Menampilkan Laporan Transaksi Penjualan Bulanan

\begin{tabular}{|l|c|c|c|c|c|}
\hline \multicolumn{1}{|c|}{ Parameter } & $\begin{array}{c}\text { Pengujian } \\
\text { 100 Baris }\end{array}$ & $\begin{array}{c}\text { Pengujian } \\
\text { 500 Baris }\end{array}$ & $\begin{array}{c}\text { Pengujian } \\
750 \text { Baris }\end{array}$ & $\begin{array}{c}\text { Pengujian } \\
1000 \\
\text { Baris }\end{array}$ & $\begin{array}{c}\text { Pengujian } \\
1500 \\
\text { Baris }\end{array}$ \\
\hline Where clause(query 1) & 0.007 & 0.0072 & 0.0072 & 0.008 & 0.0076 \\
\hline View(query 3) & 0.0105 & 0.0104 & 0.0111 & 0.0118 & 0.0124 \\
\hline Materializedview(query 5) & 0.0012 & 0.0017 & 0.0017 & 0.002 & 0.0027 \\
\hline
\end{tabular}

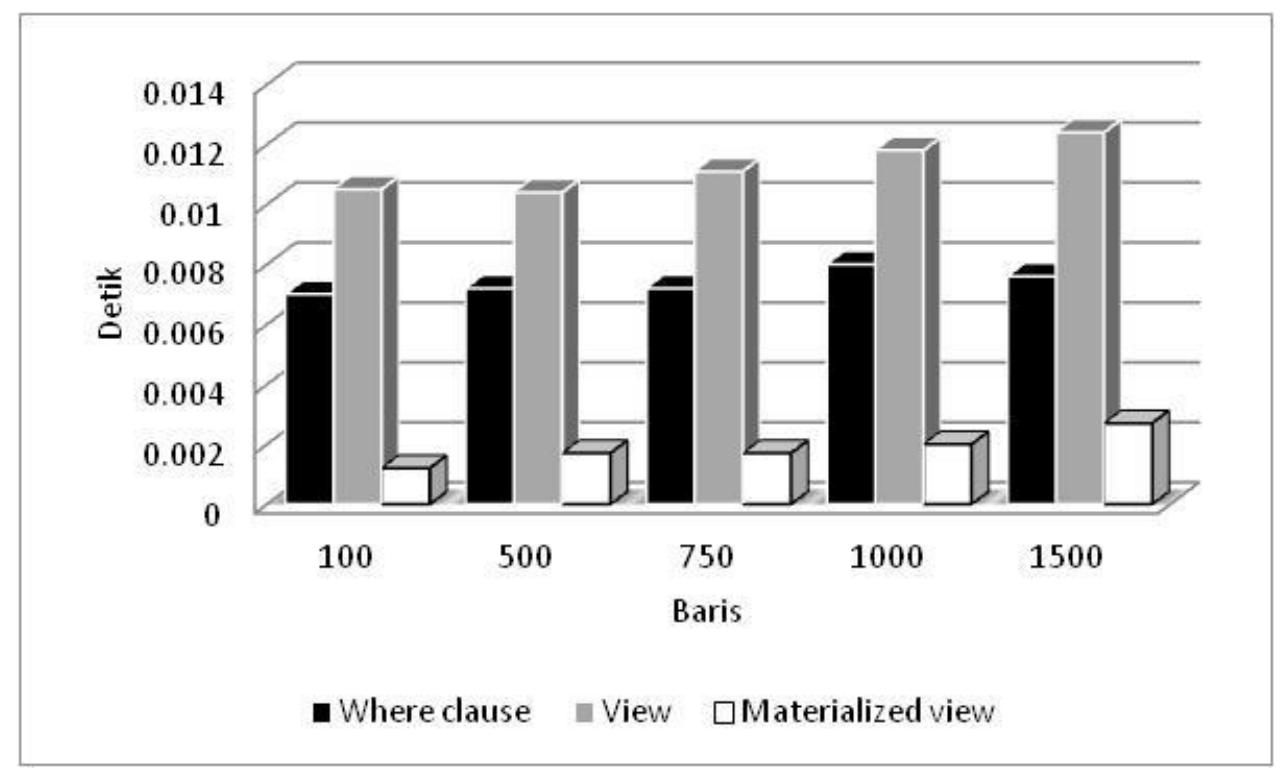

Gambar 7. Grafik Perbandingan Menampilkan Laporan Transaksi Penjualan Bulanan

Perbandingan performa kecepatan pemrosesan query untuk menampilkan laporan jumlah penjualan masing-masing item pada bulan tertentu dapat dilhat pada tabel 6 dan gambar 8 . 
Tabel 6. Hasil Perbandingan Menampilkan Laporan Jumlah Penjualan Masing-Masing Item

\begin{tabular}{|l|c|c|c|c|c|}
\hline \multicolumn{1}{|c|}{ Parameter } & $\begin{array}{c}\text { Pengujian } \\
\text { 100 Baris }\end{array}$ & $\begin{array}{c}\text { Pengujian } \\
500 \text { Baris }\end{array}$ & $\begin{array}{c}\text { Pengujian } \\
750 \text { Baris }\end{array}$ & $\begin{array}{c}\text { Pengujian } \\
1000 \\
\text { Baris }\end{array}$ & $\begin{array}{c}\text { Pengujian } \\
1500 \\
\text { Baris }\end{array}$ \\
\hline Where clause(query 2) & 0.0039 & 0.0045 & 0.0037 & 0.0045 & 0.004 \\
\hline View (query 4) & 0.0209 & 0.0174 & 0.017 & 0.0129 & 0.0113 \\
\hline Materializedview(query 6) & 0.0011 & 0.0022 & 0.0024 & 0.0024 & 0.0029 \\
\hline
\end{tabular}

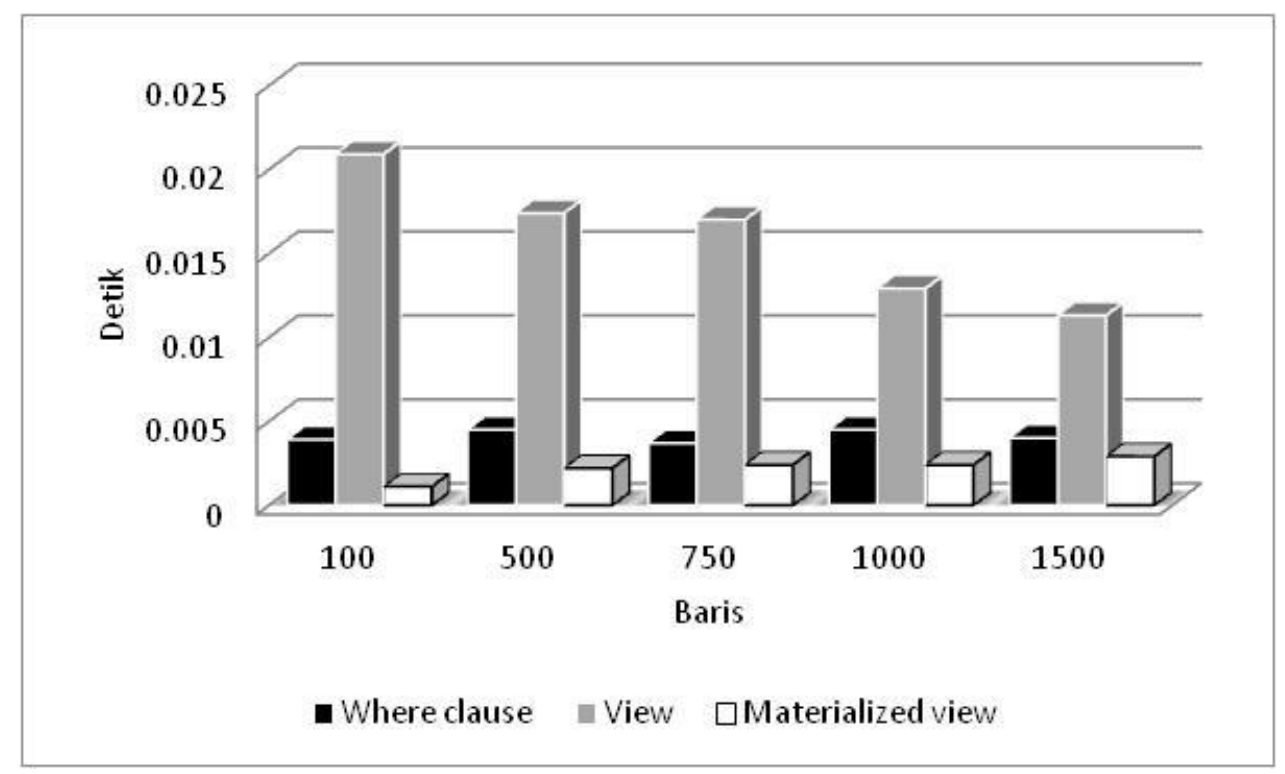

Gambar 8. Grafik Perbandingan Menampilkan Laporan Jumlah Penjualan Masing-Masing Item

Berdasarkan hasil perbandingan dalam menampilkan laporan transaksi penjualan bulanan dan laporan jumlah penjualan masing-masing item, penggunaan materialized view jauh lebih cepat dari pada menggunakan where clause maupun view. Waktu pemrosesan query pada view lebih besar dari pada menggunakan whereclause.

Setelah dilakukan beberapa eksperimen untuk membandingkan waktu pemrosesan query antara where clause, view dan materialized view, maka disarankan dilakukan optimasi query untuk meningkatkan kecepatan dalam menampilkan laporan penjualan bulanan, yang semula menggunakan where clause diganti menggunakan materialized view.

\section{KESIMPULAN}

Berdasarkan hasil pengujian diatas, dapat disimpulkan antara lain sebagai berikut.

1. Waktu pemrosesan query dengan menggunakanwhere clause untuk menampilkan laporan transaksi penjualan bulanandengan jumlah data 100, 500, 750, 1000, dan 1500 data membutuhkan waktu $0.007,0.0072,0.0072,0.008$ dan 0.0076 detik. Waktu pemrosesan query dengan menggunakan where clause untuk menampilkan laporan jumlah penjualan masing-masing item dengan jumlah data 100, 500, 750, 1000, dan 1500 data membutuhkan waktu 0.0039, 0.0045, $0.0037,0.0045$ dan 0.004 detik.

2. Waktu pemrosesan query dengan menggunakan view untuk menampilkan laporan transaksi penjualan bulanan dengan jumlah data $100,500,750,1000$, dan 1500 data membutuhkan waktu $0.0105,0.0104,0.0111,0.0118$ dan 0.0124 detik. Waktu pemrosesan query dengan menggunakan view untuk menampilkan laporan jumlah penjualan masing-masing item dengan jumlah data 100 , 500, 750, 1000, dan 1500 data membutuhkan waktu 0.0209, 0.0174, 0.017, 0.0129 dan 0.0113 detik. 
3. Waktu pemrosesan query dengan menggunakan materializedview untuk menampilkan laporan transaksi penjualan bulanan dengan jumlah data $100,500,750,1000$, dan 1500 data membutuhkan waktu $0.0012,0.0017,0.0017,0.002$ dan 0.0027 detik. Waktu pemrosesan query dengan menggunakan materializedview untuk menampilkan laporan jumlah penjualan masingmasing item dengan jumlah data 100, 500, 750, 1000, dan 1500 data membutuhkan waktu 0.0011, $0.0022,0.0024,0.0024$ dan 0.0029 detik.

4. Penggunaan materializedview untuk menampilkan laporan transaksi penjualan bulanan dan laporan jumlah penjualan masing-masing item lebih cepat dari pada menggunakan query where clause maupun view, sehingga Materialized view dapat disarankan untuk digunakan sebagai salah satu metode optimasi pada proses penarikan data laporan transaksi penjualan bulanan di Moonly Café.

\section{SARAN}

Saran dari penelitian ini adalah membandingkan performa query whereclause, view dan materializedview dengan menggunakan data yang lebih besar dari 1500 data dan membandingkan dengan menggunakan parameter lain selain parameter waktu pemrosesan query.

\section{DAFTAR PUSTAKA}

[1] Jamil, M., Rosihan, dan Fuad, A., 2016, Cloud Computing : Teori dan Aplikasi, Deepublish, Yogyakarta.

[2] Sutiani, D., 2010, IBM Database - DB2 for Beginners, Elex Media Komputindo, Jakarta.

[3] Coronel, C., dan Morris, S., 2016, Database Systems: Design, Implementation, and Management , Cengage Learning, Boston, United States of America.

[4] Patel, D., dan Patel, P., 2015, An Approach for Query Optimization by using Schema Object Base View, International Journal of Computer Applications, Vol. 119, No. 16, 21-24, :http://citeseerx.ist.psu.edu/viewdoc/download?doi=10.1.1.695.3161\&rep=rep1\&type=pdf.

[5] Sudaryanto, S. N., 2007, Optimasi Query Database Menggunakan Teknik Heuristic, Techno.com, Vol. 7, No. 2, 53-66, :http://dinus.ac.id/wbsc/assets/dokumen/majalah/Optimasi_Query_Database_Menggunakan_Tek nik_Heuristic1.pdf.

[6] Jogekar. R. N., dan Mohod, A., 2013, Design and Implementation of Algorithms for Materialized View Selection and Maintenance in Data Warehousing Environment, International Journal of Emerging Technology and Advanced Engineering, Vol. 3, No. 9, 464-470, :https://pdfs.semanticscholar.org/6619/08d9000559b1aff343b66e047e8713daa8a3.pdf 